\title{
The Proceedings of the International Conference
}

on Creationism

Volume 8

Print Reference: Pages 238-247

Article 33

2018

\section{A Characterization of Petrified and Mummified Wood from an Eocene Deposit in Mississippi}

Nayeon Lee

Mississippi State University

Sungkwang Mun

Mississippi State University

Follow this and additional works at: https://digitalcommons.cedarville.edu/icc_proceedings

$M$ ark Horstemeyer

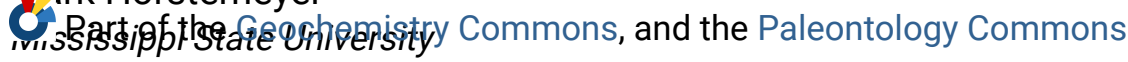

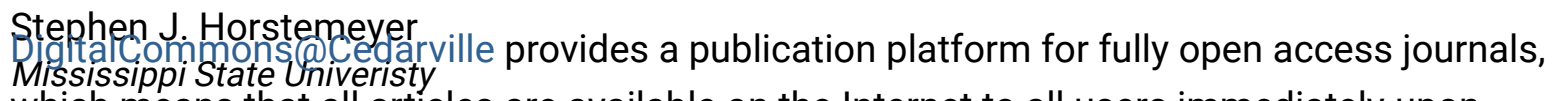
which means that all articles are available on the Internet to all users immediately upon Pavipdedibanglowever, the opinions and sentiments expressed by the authors of articles Alissisfiedi intater jourersalty do not necessarily indicate the endorsement or reflect the views of DigitalCommons@Cedarville, the Centennial Library, or Cedarville University and its employees. The authors are solely responsible for the content of their work. Please address questions to dc@cedarville.edu.

Browse the contents of this volume of The Proceedings of the International Conference on Creationism.

\section{Recommended Citation}

Lee, N., S. Mun, M.F. Horstemeyer, S.J. Horstemeyer, and D.J. Lang 2018. A characterization of petrified and mummified wood from an Eocene deposit in Mississippi. In Proceedings of the Eighth International Conference on Creationism, ed. J.H. Whitmore, pp. 238-247. Pittsburgh, Pennsylvania: Creation Science Fellowship. 


\title{
A CHARACTERIZATION OF PETRIFIED AND MUMMIFIED WOOD FROM AN EOCENE DEPOSIT IN MISSISSIPPI
}

\author{
Nayeon Lee, Center for Advanced Vehicular Systems, Mississippi State University, Mississippi State, MS 39762, USA \\ nayeon@cavs.msstate.edu \\ Sungkwang Mun, Center for Advanced Vehicular Systems, Mississippi State University, Mississippi State, MS 39762, USA \\ Mark F. Horstemeyer, Center for Advanced Vehicular Systems, Mississippi State University, Mississippi State, MS 39762, USA \\ S.J. Horstemeyer, Center for Advanced Vehicular Systems, Mississippi State University, Mississippi State, MS 39762, USA \\ David J. Lang, Department of Plants and Soil Sciences, Mississippi State University, Mississippi State, MS 39762, USA

\section{ABSTRACT}

This study experimentally investigates pieces of fossilized wood that include both mummified and petrified portions within the same pieces collected from the Red Hills Lignite Mine in Mississippi, USA. To the authors' knowledge, having petrified and mummified regions within the same piece of wood has not been previously reported. Our study analyzes the chemical compositions, microstructures, and nanohardness to characterize the fossilized wood. The chemical analysis revealed that the composition of the mummified regions included mainly carbon, oxygen, and small amount of minerals indicating these regions were similar to currently growing wood, and the petrified regions included silicon and oxygen indicating these regions were petrified-in the same piece of wood! This chemical analysis verified the mummified/petrified wood regions in multiple pieces of wood. Micrographs showed that the mummified regions retained well-preserved wood cell structures, and the petrified regions retained recognizable plant structures. Based on the wood cell structures, we confirmed that the wood originated from a species of conifer. Nano-indentation results showed the nanohardness of the petrified region to be $4.57 \pm 3.11 \mathrm{GPa}$ and the mummified region to be $0.71 \pm$ $0.39 \mathrm{GPa}$. These hardness results also confirm that the petrified regions and mummified regions were clearly different materials as the silicate region is known to be much harder than the carbon regions. With respect to the environmental condition that enabled petrification and mummification within the same pieces of wood, this evidence suggests that a heavy flood buried wood that was then covered by sediment resulting in anoxic conditions within a short time. Water from heavy rain receded to make xeric conditions while some remained causing petrification.

\section{KEY WORDS}

petrified wood, mummified wood, Mississippi embayment, Paleocene, Eocene

\section{INTRODUCTION}

Fossilized wood can provide opportunities for insight into geological history. Climatic changes can cause wood to petrify or mummify depending on the environmental conditions. Although petrification has been thoroughly investigated for years, the process is still not well understood. In theory, petrification occurs in two geological conditions: (1) when trees are buried by volcanic ash and (2) when trees are buried in fluvial sediments or floodplains with fine-grained mud (Mustoe 2003). In modern hot-springs, like those

found in Japan and Yellow Stone National Park, wood specimens recently exposed to silica-laden water exhibited the beginning stages of petrification, confirming rapid mineralization ((Akahane et al. 2004; Leo and Barghoorn 1976). Many pieces of petrified wood discovered recently at the site of Mount St. Helens after its volcanic eruption in 1980 were mineralized rapidly thus petrifying the wood and was a similar process to the modern hot springs scenario where volcanic ash brought an elevated temperature
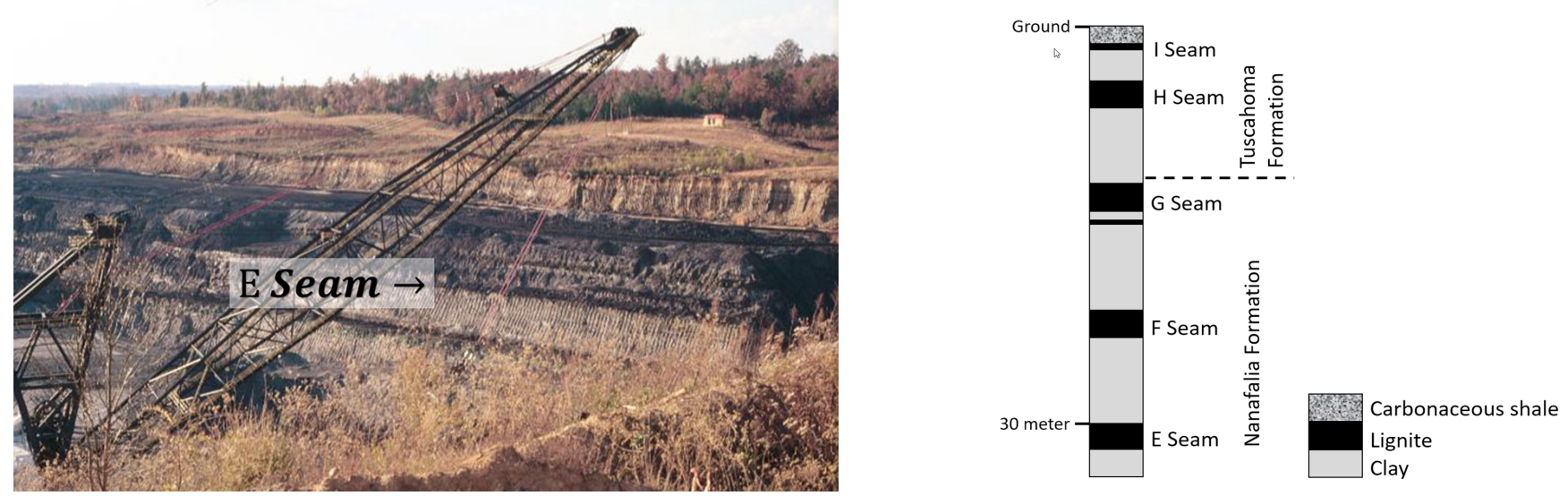

Figure 1. The location where the specimens were collected in the Red Hills Lignite Mine, MS, USA ( $33^{\circ} \mathrm{N}$ latitude). Left: The samples were from the 'E seam,' which is one of the available lignite seams in Mississippi. Right: A schematic of the stratigraphic profile (Jardine and Harrington, 2008) showing the E seam is 30 meters below the current surface as a part of what is called the Nanafalia formation of the Wilcox Group. 
and a slightly acidic pH (Karowe and Jefferson 1987: Riggs et al. 2003). However, Weibel (1996) reports of petrified wood that was discovered in sediment with no history of hot springs or volcanoes.

In this study, fossilized wood pieces were collected from the Red Hills Lignite Mine, MS, USA ( $33^{\circ} \mathrm{N}$ latitude). These specimens were collected by Dr. David Lang in 2008. Figure 1 shows that the specimens were found in the "E seam," which is $30 \mathrm{~m}$ below the current surface level and a part of the Nanafalia formation of the Wilcox Group. The lignite seam is occasionally intercalated by clay layers ranging between 0.2 and $1.5 \mathrm{~m}$. According to conventional evolutionary history, the Nanafalia Formation was deposited during the Late Paleocene-Early Eocene epochs 56+ million years ago Dockery and Thompson 2016). In geological history, Mississippi does not show evidences of experiencing volcanic activity past the Cretaceous Period (65-135 million years ago according to evolutionary history).

In the Red Hills Lignite Mine, wood is preserved in three ways: lignification (coalification), siliceous petrification, and mummification (Blackwell and Marak 1989). Coalification converts wood into lignite, a process in which internal wood structures can be preserved. Petrification also preserves the original wood structures. Petrification is traditionally known to occur through two preservation processes: permineralization or replacement. Permineralization occurs when pores or cavities are filled with minerals. Replacement occurs when the original organic materials are replicated by inorganic minerals. Recently, Mustoe (2017) argued that these two processes are not independent, but, rather occur contemporaneously. If the alternative material is a silica (silicon dioxide), it is specifically called "silicification." Silicification even varies within a single specimen: cell wall mineralization or silica deposition in open pores by permeation (Mustoe 2015; Oehler and Schopf 1971). Petrified wood is the most common type of fossilized wood in Mississippi and was designated the state stone of Mississippi in 1976. Another type of fossilized wood is mummified wood in which original organic wood has been preserved through dehydration; in other words, the wood has not been permineralized and was buried rapidly likely due to a catastrophic event, such as the Genesis Flood or a subsequent local catastrophe. Although mummified wood occurs abundantly in Mississippi (Brown 1938), it has not been well reported, and

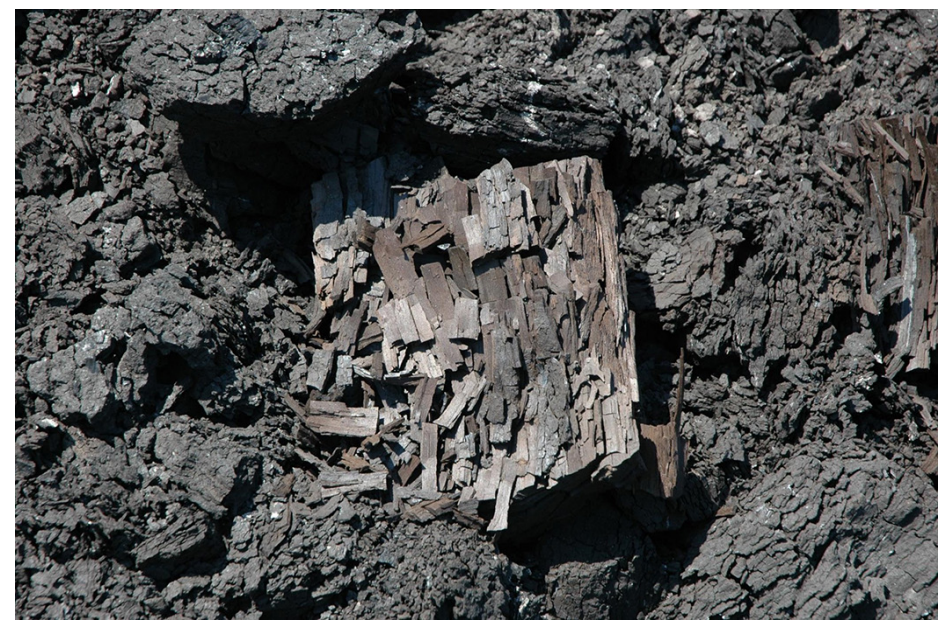

the mummification process remains unknown. Reports of Eocene mummified wood was found in Europe, Antarctica, and the Arctic (Erdei et al. 2009; Jahren 2007; Jefferson 1982; Vassio et al. 2008; Wolfe et al. 2012). These authors make comments about "sudden inundation," revealing a high rate effect that occurred in the conditions to induce this phenomenon. The worldwide occurrences indicate that a worldwide event such as Noah's Flood was likely causative.

Fossilized wood specimens exhibiting petrified regions and mummified regions on each side of the same piece of wood were examined to investigate the geological history in Mississippi. Since the samples were collected in the lignite mine, coalification, petrification, and mummification could occur within the same depositional sediments. However, in this study, the focus was on petrification and mummification because of the particular specimens that we found.

\section{METHOD}

Figure 2a is a photograph of what appears to be mummified wood in the middle of a lignite pile with petrified wood at the lignite mine. Figure $2 b$ is a photograph one of the samples used for experiments. The right side of the sample is petrified wood, while the left side of the sample is mummified wood. These wood pieces were hauled from the 'E seam' in the Red Hills Lignite Mine with large mining equipment.

These samples were used to examine the microstructure, chemical composition, and hardness of the material. The structures of the samples were characterized by using an optical microscope and a Scanning Electron Microscope (SEM). Petrified and mummified wood samples were cut and mounted into epoxy using a cold mount technique and then thoroughly polished to observe the cross section. Four other samples including petrified, partially petrified, mummified wood, and lignite were prepared in order to study the fracture surfaces using a Carl-Zeiss Supra40 Field Emission Gun (FEG)-SEM. Each sample was sputter coated with a gold/palladium mixture. The Energy Dispersive Spectroscopy (EDS) on the SEM was also used to carry out chemical analysis of the petrified wood and mummified wood. EDS analysis measured the relative amount of weight for each chemical component. In order to measure hardness at the nanoscale, nano-indentation tests were conducted using a Triboindenter ${ }^{\circledR}$ (Hysitron Incorporated, Minneapolis) with

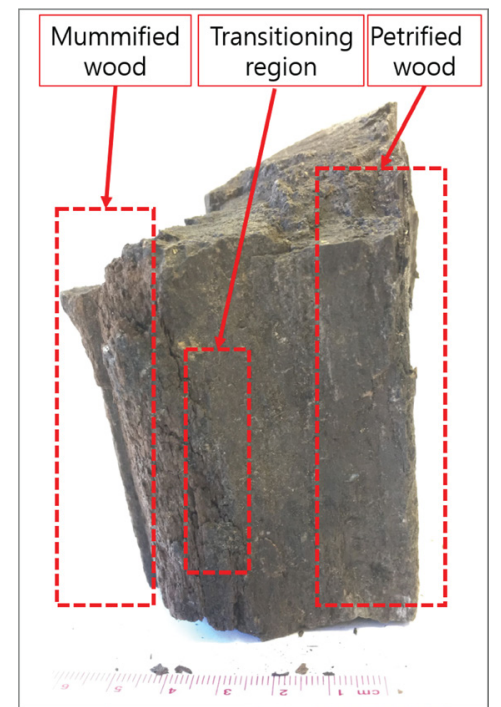

Figure 2. Left (2a): Mummified wood in the middle of lignite pile at the site of Red Hills Lignite Mine, MS. Right 2(b): A single piece of fossilized wood including regions of mummified wood and petrified wood. 
a Berkovich tip indenter. The loading condition was controlled as follows: a 10 -sec loading segment, a 10 -sec unloading segment, and $5000 \mu \mathrm{N}$ applied maximum load.

\section{RESULTS}

\section{Chemical Composition}

Figure 3 shows the chemical composition of mummified wood and petrified wood. The petrified wood region is $36.5 \pm 3.2 \%$ oxygen and $63.5 \pm 3.2 \%$ silicon and is totally petrified without the organic material containing carbon. The mummified wood region is 80 $\pm 1.3 \%$ carbon, $16.9 \pm 1.7 \%$ oxygen, $0.9 \pm 0.4 \%$ sulfur, and 1.3 $\pm 0.4 \%$ calcium. Compared to living wood which contains $50 \%$ carbon, $42 \%$ oxygen, $6 \%$ hydrogen, $1 \%$ nitrogen, and $1 \%$ other elements such as calcium and sulfur (Pettersen 1984). The relative carbon weight is much greater for the mummified wood. One possible reason for a greater relative amount of carbon and a lower relative amount of oxygen and hydrogen in the mummified wood is that the mummified wood was completely dehydrated. In living wood, water is present thus increasing the amounts of oxygen and hydrogen. The primary difference between mummified wood and living wood is the amount of water.

\section{Hardness}

Nano-indentation results revealed that the nanohardness of the petrified region was $4.57 \pm 3.11 \mathrm{GPa}$, and the mummified region was $0.71 \pm 0.39 \mathrm{GPa}$. The hardness values have a fairly large deviation because the sample contained pores from the original wood cells. In spite of the deviations in measurements, the hardness values of petrified wood were 6-7 times greater than those of the mummified wood, thus confirming that petrified wood and mummified wood are different materials. Furthermore, one would anticipate that the hardness would be greater for the petrified region when compared to the mummified region as silica is much harder than carbon.

\section{Microstructures \\ A. Petrified Wood}

Figure 4 shows the images on the polished surface of the petrified wood sample in the transverse orientation taken by an optical microscope (a-b) and an SEM (c-d). Wood tracheid, which is a water conducting cell in the xylem of wood, are divided into two wood cells: early wood and late wood. Early wood is laid down first in the first half of the growing season and less dense with a larger lumen area. On the other hand, late wood is laid down in the second half of the same growing season and denser with a smaller lumen area. The early and late wood compose a clear periodic pattern especially in conifers as shown in Figure 4a (Higuchi, 1997). Figure 4a shows that these late wood cells and early wood cells appear as alternating bands. Figure $4 \mathrm{~b}$ shows closer examination of the late wood cells revealing uncollapsed cell walls filled with mineral deposits. Figure 4c shows the early wood and late wood, and Figure 4d shows a line of semi-circular openings and highly compressed cell walls. It is probable that large compressive loads from the Genesis Flood, whether during or afterward, might occur before mineralization because mineralization induces a brittle fracture behavior of which was not observed in the petrified regions of the specimens.

Fracture surfaces of the petrified wood were also observed using the SEM. Figure 5 shows a preserved tracheid. In a longitudinal direction, it is noticeable that the surface of the tracheid is petrified; also, the inside of the tracheid is filled with silica mineralization (Figure 5a). In the transverse direction, the wood cell structure is not preserved in a perfect geometric shape although the cell shape is recognizable. However, one can note that the cell wall is mineralized, and the individual cells are filled with silica (Figure $5 b)$.

\section{B. Transition Region Between Petrified Wood and Mummified Wood}

Figure 6 shows optical micrographs of the transition region between the mummified region and the petrified region of the same piece of wood from the polished sample. Figure 6a shows the petrified regions interspersed among the mummified wood region. When examined under higher magnification, the compressed wood cell structures in the mummified wood region are apparent. Figure $6 \mathrm{~b}$ shows a noticeable boundary between the petrified region and the mummified region. Note that there is no transitioning gradient of material between the petrified wood and the mummified wood at the microscale. Each region of the petrified wood and the mummified wood is distinguishable and not merged together.

Clearly, both regions are the same age, but the chemical compositions and the associated chemical reactions are indicative of different chemical processes in the past. Also, these results indicate that the levels of heat and pressure were the same since the regions are so close to each other and yet distinguishable. If there were a material gradient transition between the petrified and mummified regions, one could expect that a heat gradient or pressure gradient induced the different chemical reactions in the two regions. In the absence of the material gradients, it appears that the pressure and temperature did not play a significant role during this fossil wood formation. Sigleo (1979) also reported that the silicification process occurred at the surface temperature and pressure associated with typical surface and groundwater conditions.

\section{Mummified Wood}

Figure 7 shows the cellular structures of the mummified wood. In the longitudinal direction, the wood tissue of the tracheid and rays are well preserved (Figure 7a-c). It is also noticeable that border pits in the tracheid wall are well preserved. On the tracheid wall, there are cracks initiated from the pits or along the wall, and most of the cell walls buckled and delaminated (Figure 7d-e). The transverse direction shows delamination that would arise from dehydration and that the cell tracheid lumens were extremely compressed as buckling is shown in Figure 7e. One can employ the buckling equation for free pipe derived from Euler's buckling theory for a critical pressure, $P_{c r}$ (Figure 8 ). The buckling formula is given by

$$
P_{c r}=\frac{E}{1-\gamma^{2}}\left(\frac{t}{D}\right)^{3}
$$

where $\mathrm{E}$ is the elastic modulus of the tracheid lumen ( $7 \mathrm{GPa}$ for a conifer), $\mathrm{t}$ is the thickness of the tracheid $(6 \mu \mathrm{m})$, and $\mathrm{D}$ is the diameter of the tracheid $(15 \mu \mathrm{m}) . \gamma$ is a Poisson's ratio, which is the ratio of the transverse to axial strain. Here, the Poisson's ratio of Baldcypress at $12 \%$ moisture content is used, which is 0.411 . The critical buckling pressure, $P_{c r}$, turns out to be $539 \mathrm{MPa}$, which is equivalent to $5,506 \mathrm{~kg} / \mathrm{cm}^{2}\left(78,314 \mathrm{lb} / \mathrm{in}^{2}\right)$. This large pressure would come from either sediment onto the wood or wood compressing under large motions from turbulent water transport or from the post-Flood inundations. While most of the cell walls buckled, some of the lumens remained with structural integrity (Figure 7f-g).

\section{DISCUSSION}

Thick deposits of peat are needed to form the lignite layers. Peat is compacted to about one-third of its original volume during coalification due to volume loss from compression and loss of organic 
(a)

Petrified Wood

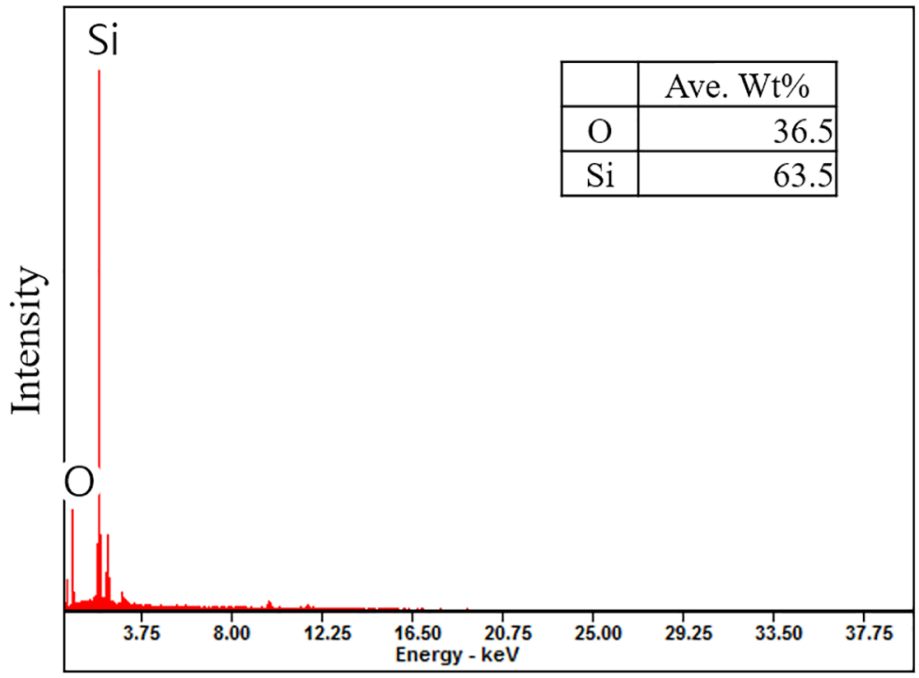

(b)

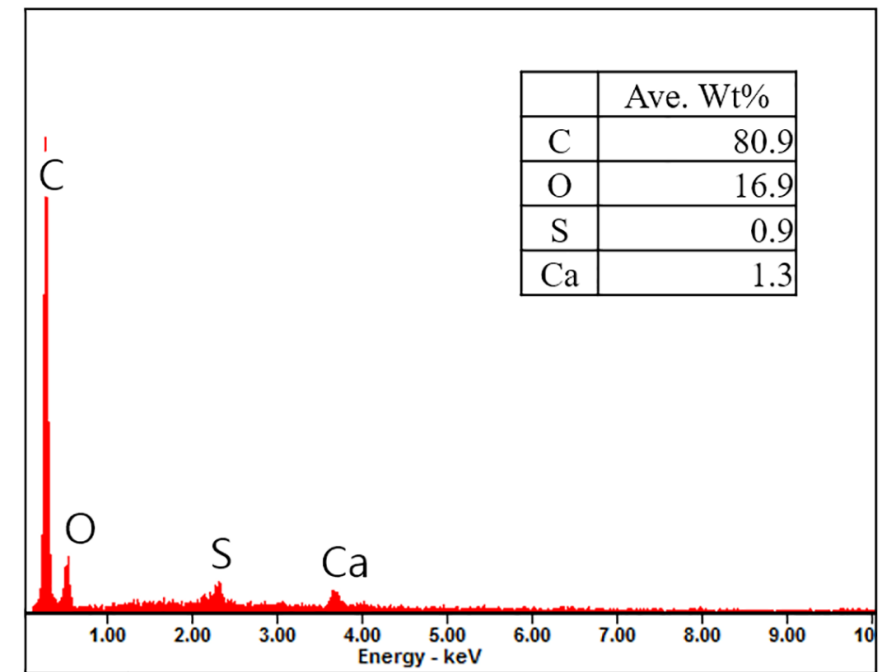

Figure 3. Chemical composition analysis using Energy Dispersive Spectroscopy (EDS) revealed that (a) the petrified wood region was $36.5 \pm 3.2 \%$ oxygen and $63.5 \pm 3.2 \%$ silicon, and (b) the mummified wood region was $80 \pm 1.3 \%$ carbon, $16.9 \pm 1.7 \%$ oxygen, $0.9 \pm 0.4 \%$ sulfur, and $1.3 \pm 0.4$ $\%$ calcium.
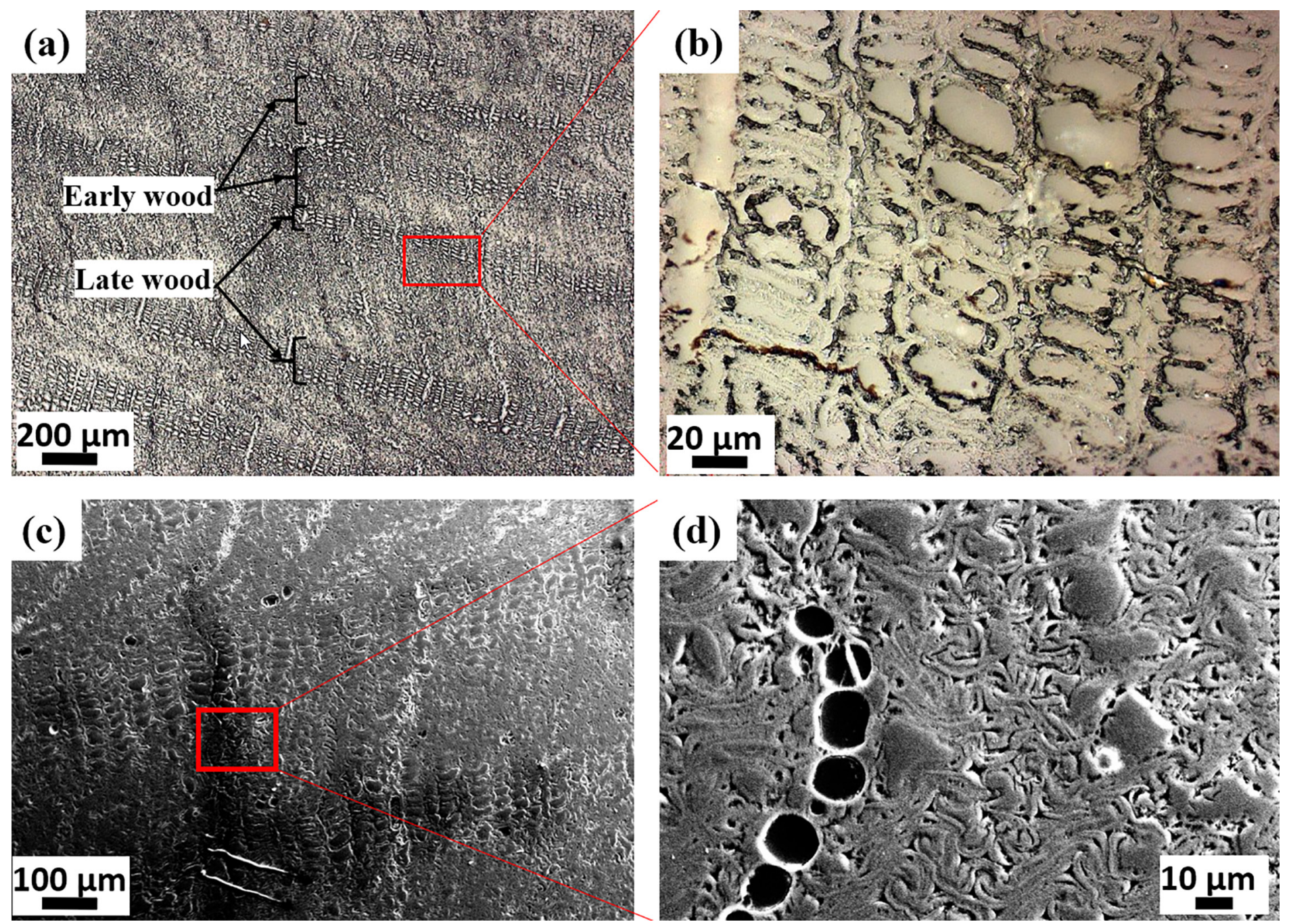

Figure 4. Images of the polished petrified wood. Optical micrographs show (a) alternating band structures illustrate regions of late wood and early wood; (b) the late wood tracheid cells are filled with silica; (c) Scanning Electron Microscope (SEM) images show the alternating bands too; and (d) preserved open cells on the left and compressed cells in early wood tracheid region on the right are shown via SEM. 
matter (Shearer and Moore 1996). The lignite layer in the Red Hills

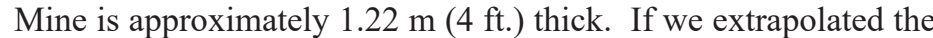
Shearer and Moore (1996) calculations to the Red Hills Mine, then the original wood peat would have been approximately $4.4 \mathrm{~m}$ (14.3 $\mathrm{ft}$.) thick. Based on our field observations of the lignite layer's texture and microscopy analysis, we observed compaction of wood and cell wall buckling in this material confirming the densification process. In order to have $4.4 \mathrm{~m}$ of wood peat, a huge forest would have existed in Mississippi in the past or the Genesis Flood brought a large mass of forest products to the region once the Flood waters drained off of the "then" USA. Evolutionary geologists (Blackwell and Marak 1989; Cushing et al. 1964; Dockery and Thompson 2016) claim that during the Late Paleocene and Early Eocene, a majority of Mississippi existed as an alluvial plain characterized by a low and marshy land with luxuriant plant growth. Thus, the lignite originated from ancient plants in the delta plains and swamps under tropical climate conditions. Alternatively, the Bible tells of a different geological history. Lush growth of plants that now became coal or fossilized was from pre-Flood period in 60004500 years ago. During those days, the climate was optimized for plants to thrive and grow. During the worldwide Flood described in Genesis, a great volume of wood was rooted up and deposited by water most probably in a different location.

In order to form silicified wood from trees, there should be silicabearing water near buried trees for petrification to occur. The solubility of silica in water is very low at room temperature and environmental pressure. However, silica dissolves in water much more readily at a high pressure or a high temperature (Fournier and Rowe 1977). The preferable condition for petrification to occur would be in the vicinity of volcanos where volcanic ashes are located. These ashes lower the $\mathrm{pH}$ and provide_silica. In the fluvial sediment of the Red Hill mine without volcanic activity, it is still unknown how silica dissolved into water and how petrification initiated. It is, however, apparent that silica-laden water permineralized one part of the wood pieces found in our study. The piece of wood shown in Figure $2 b$ indicates that only a part of the wood stem contacted water while the other part did not. As the water receded after the wood was buried in fluvial sediments, the wood dehydrated while some silica bearing water was trapped between the wood layers.

While a part of the wood experienced petrification, another region experienced mummification at the same time. One of the prominent paleobotany textbooks entitled 'Paleobotany: the biology and evolution of fossil plants' (Taylor et al. 2009) described mummification as:

"When conditions of burial are rapid, and especially in very dry or cold environments, wood or other plant parts may survive for millions of years in a relatively unaltered condition. Such mummified remains have been described from Cenozoic deposits and represent a special preservation type in which the plant tissue was rapidly dehydrated and buried."

This theory fails to explain the origination of our samples in two aspects. First, contemporary paleobotanists assume that mummification occurred in a very dry or cold condition. However, our samples were found in a subtropical humid condition in Mississippi, where it is neither very dry nor cold. Cellulose and lignin, which are the main components of wood, are susceptible to microbial decay. A very dry and cold environment suppresses microbial activity so that wood would be preserved. However, in a humid environment like Mississippi, other conditions are required to protect wood from microbial activities. One possible condition is to deplete oxygen to rule out major decaying processes caused by aerobic microbial activity. To achieve this, the time between accumulation of the wood layers and the next sediment layer would be fairly short. Second, the sequence of burial and dehydration is not applicable to our samples. The theory (Taylor et al. 2009) assumes that plants dehydrated first and then buried. This fails to explain our samples in which petrified wood and mummified wood co-exist. Because petrification generally occurs in the mineralrich water, the whole wood might be in a relatively wet condition

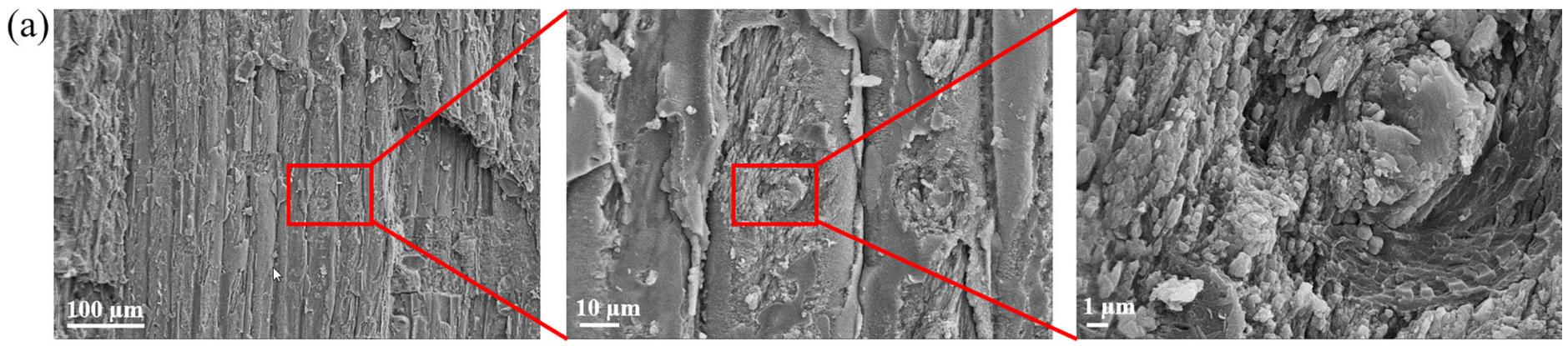

(b)

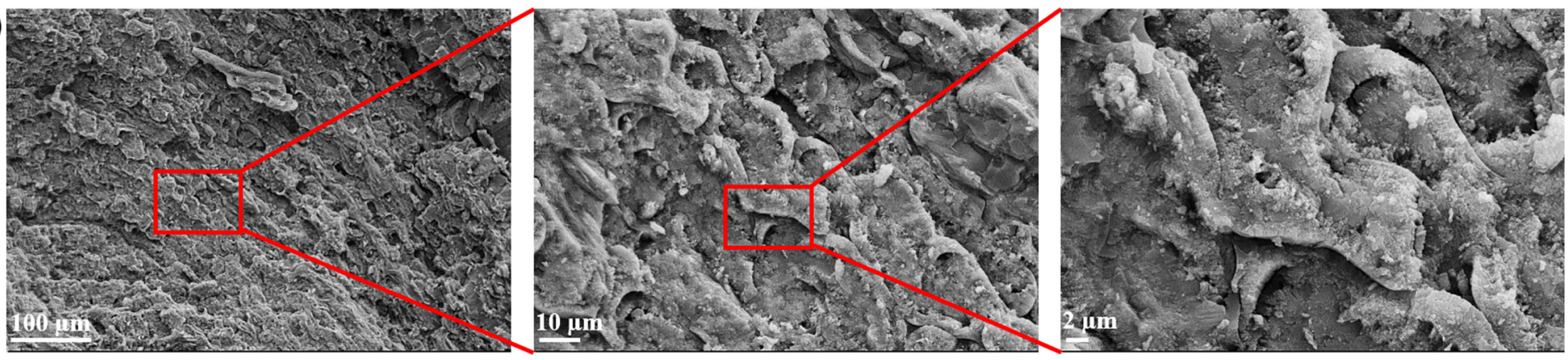

Figure 5. Scanning Electron Microscope (SEM) images of the fractured petrified wood (a) in a longitudinal orientation shows the silicon mineralized tracheid and (b) in a transverse direction shows distorted tracheid lumens filled with silicate mineral. 

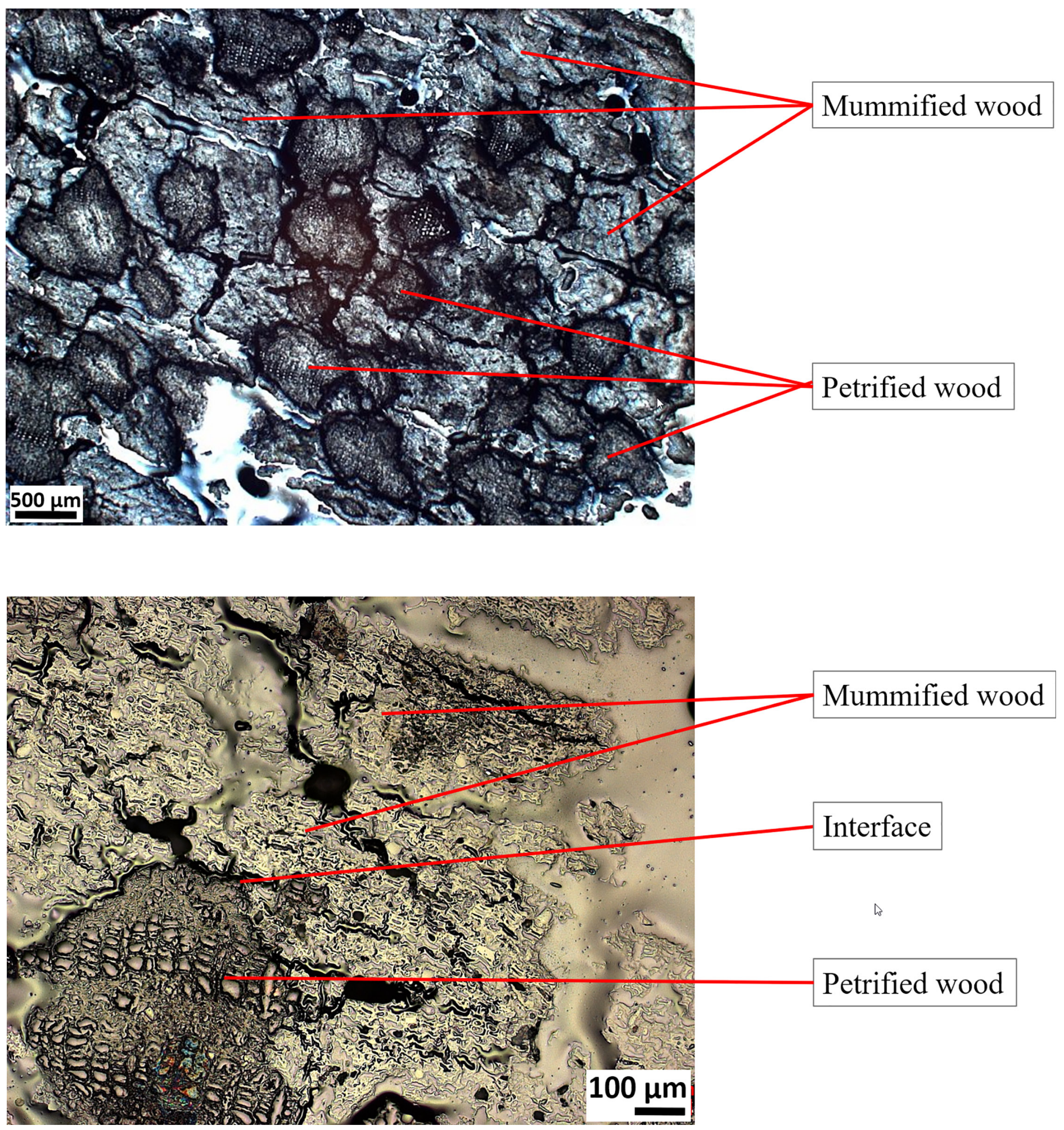

Figure 6. Optical microscopic images of the transition region between the mummified regions and petrified regions illustrated from the transverse direction. (a, top) Petrified wood is interspersed in the mummified wood. (b, bottom) A distinct interface between the mummified region and petrified region illustrates a lack of gradient. 

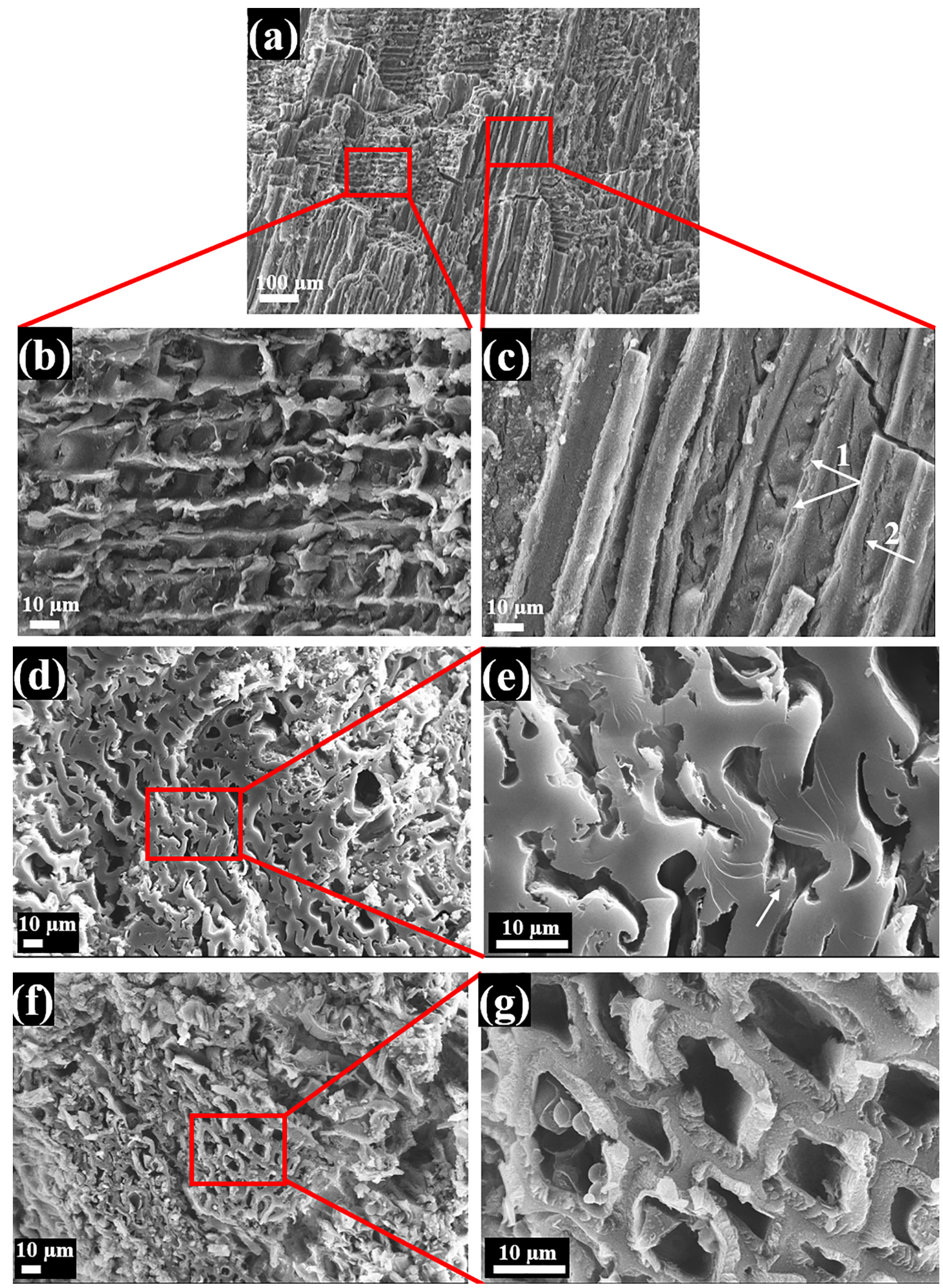

Figure 7. Scanning Electron Microscope (SEM) images of the fractured surfaces of the mummified wood in the longitudinal direction (a)-(c) and in the transverse direction (d)-(g). Illustrated are (a) tracheid which runs in a vertical direction, and rays which runs in a horizontal direction, (b) preserved ray structure under higher magnification, and (c) preserved tracheid structure with bordered pits (indicated by the arrow 1) and crack (indicated by the arrow 2). In the transverse direction, it is observed (d) a collapsed late wood tracheid, and (e) damaged and delaminated (indicated by the arrow) late wood tracheid wall in a zoomed-in view. (f) Uncollapsed tracheid lumens were also observed, and (g) a zoomed-in view showing the cell lumens that remained open. 
immediately after burial. Then, there would be a successive process to decrease water content in the wood. According to the theory, mummification cannot occur at flooding since it requires dehydration before burial. Yet, our Mississippi samples supports the Flood scenario that dehydration might occur after the burial. In order to dehydrate the wood, in Mississippi, salinization may have played a role. The Mississippi Embayment contains multiple layers of lignite coal with interburdens of silts and clays from both marine and freshwater inundations (Dockery and Thompson, 2016). The Red Hills Mine located in the Nanafalia formation is composed of marginal marine sediment that purportedly originated from USA gulf coast (Harrington 2008). Mummified wood forests reported in Ireland and Florida in the USA might be preserved through salt-water intrusion (Lewis et al. 2003). There is also a report of a mummified forest underwater off the coast of Alabama that was exposed by Hurricane Ivan in 2004 (Holley 2017). However, our chemical analysis does not detect typical salt compound (sodium chloride) from the mummified sample.

In summary, we hypothesize that the wood stem that appears to be mummified on one side and fully petrified on the other (Figure 1) had its provenience lot in the sediment with the horizon boundary facing toward the flow of water as it became petrified. The mummified portion had reduced moisture or xeric conditions within a very short time frame. Similar to the conditions found in the Egyptian dessert where bodies were buried and became naturally mummified (Smithsonian; Royal Ontario Museum). The earliest mummies found in Egypt from prehistoric times probably were accidental, because by chance there was dry sand and air that preserved some bodies buried in shallow pits dug into the sand (Smithsonian Institute). This has also been found in China with bodies dating from the Ming Dynasty (Reese 2014). During the following Ice Age after the Flood, drier conditions would bring about desiccated wood. It would not be as dry as a desert, but the humidity would certainly decrease. Conditions during the Flood would have saturated the marshes and bogs containing conifers and other vegetation and these findings suggest that post-Flood conditions might be rapidly xeric. Work done by Dr. Lang et al. (2008) at the Red Hills Lignite Mine found layers of floodplain strata to the $\mathrm{H}$ seam in an alluvial floodplain where it was relatively dry below the I seam (Figure 1), even though the surface agricultural soil from Mississippi's subtropical humid climate was saturated with water to the depth of 2 meters from $1500 \mathrm{~cm}$ of precipitation. Current climatic conditions stimulate rapid decay of all contemporary wood within a few short years. Therefore, it is highly unusual and very noteworthy that pristine mummified wood has been found in Mississippi at $33^{\circ} \mathrm{N}$ latitude. This is documented by noted paleontologist/paleobotanist Mustoe (2017). He examined wood pieces similar to the ones shown in this document collected from Mississippi by one of this paper's coauthors Dr. David Lang. Dr. Mustoe was astounded that permineralized and pristine wood was found coexisting on the same specimen that he identified as a conifer. Before our finding, nowhere else worldwide was such woods reported except north of the Arctic Circle on Ellesmere Island at $82^{\circ} \mathrm{N}$ latitude (Jahren 2007). Still, this sample having petrified wood and mummified wood on the same piece remains a mystery.

\section{CONCLUSIONS}

Several conclusions can be inferred from this research study:

1. Several pieces of a conifer wood found in the Red Hills Lignite Mine, Mississippi contained pieces of wood that had both petrified and mummified regions in the same piece. Multiple materials characterization methods illustrated stark differences with internally consistent data that confirmed one piece of wood contained both petrified and mummified regions

2. The preservation of the different kinds of wood adjacent to each other along with single pieces of wood that were found in a warm climate at $33^{\circ} \mathrm{N}$ latitude in Eocene strata in Mississippi contain both petrified and mummified regions casts strong doubt that this Eocene wood is 50 million years old.

3. We can deduce rapid changes in the environment due to petrification and mummification occurring on the same piece of the wood. Petrification requires substantial quantities of a mineralrich fluid available before decay takes place. At the same time, mummification occurred when wood was dehydrated before decay. We would suggest a causative scenario that there was a heavy flood that buried wood that was then covered by sediment resulting in anoxic conditions within a short time. Water from heavy rain receded to make xeric conditions while some remained thus causing petrification.

\section{FUTURE WORK}

1. Where and how did silica dissolve in water for silicification?

2. Coalification, petrification, and mummification occurred to the same source of wood in one place. What brought about the slight differences to these different chemical reactions resulting in lignite, petrified wood, and mummified wood?

3. Thorough chemical analysis on mummified wood.

\section{REFERENCES}

Akahane, H., T. Furuno, H. Miyajima, T. Yoshikawa, and S. Yamamoto.

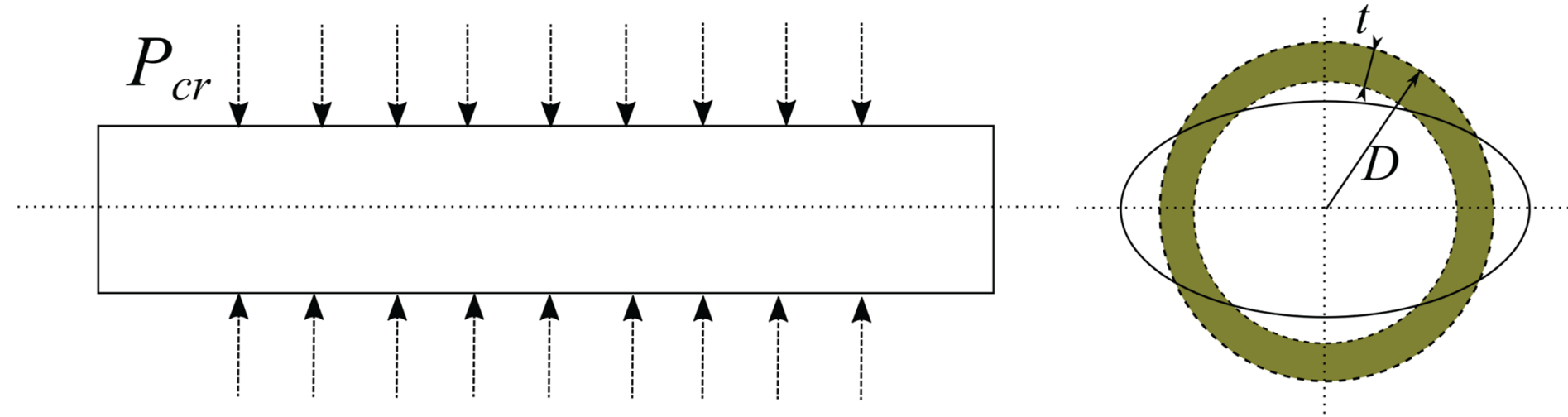

Figure 8. A schematic of the pipe buckling. Employing a pipe buckling formula, the critical pressure $\left(\mathrm{P}_{\mathrm{cr}}\right)$ causing a buckling in the tracheid of the mummified wood is calculated as $539 \mathrm{MPa}$. 
of silicification of wood during the Earth's history. Sedimentary Geology 169, no. 3-4:219-228.

Blackwell, W.H., J.H. Marak. 1989. The Scientific investigation of fossil wood. Mississippi Geology 10, no.1 (September):1-9.

Brown, C.A., 1938. The flora of Pleistocene deposits in the western Florida parishes, West Feliciana parish, and East Baton Rouge parish, Louisiana. Louisiana Geological Survey Geology Bulletin 12:59-96.

Cushing, E.M., E.H. Boswell, and R.L. Hosman. 1964. General geology of the Mississippi embayment. US Geological Survey Professional Paper 448, B1-B28.

Dockery, D.T., and D.E. Thompson. 2016. The geology of Mississippi. Jackson: University Press of Mississippi.

Erdei, B., M. Dolezych, and L. Hably. 2009. The buried Miocene forest at Bükkábrány, Hungary. Review of Palaeobotany and Palynology 155, no. 1-2:69-79.

Fournier, R.O., and J.J. Rowe. 1977. Solubility of amorphous silica in water at high temperatures and high pressure. American Mineralogist 62:9-10.

Harrington, G.J. 2008. Comparisons between Palaeocene-Eocene paratropical swamp and marginal marine pollen floras from Alabama and Mississippi, USA. Palaeontology 51, no. 3:611-622.

Higuchi, T. 1997. Formation of earlywood, latewood, and heartwood. Biochemistry and Molecular Biology of Wood, pp. 291-307. Springer: Berlin, Heidelberg.

Holley, P. 2017. A mysterious underwater forest warns of Earth's rapidly changing climate. The Washington Post [June 29].

Jahren, A.H. 2007. The Arctic forest of the middle Eocene. Annual Review Earth Planet Science 35, 509-540.

Jardine, P.E., and G.J. Harrington. 2008. The Red Hills Mine palynoflora: A diverse swamp assemblage from the Late Paleocene of Mississippi, U.S.A. Palynology 32, no. 1:183-204.

Jefferson, T.H. 1982. Fossil forests from the lower Cretaceous of Alexander Island, Antarctica. Palaeontology 25, 681-708.

Karowe, A.L., and T.H. Jefferson. 1987. Burial of trees by eruptions of Mount St Helens, Washington: Implications for the interpretation of fossil forests. Geology Magazine 124, 191-204.

Lang, D., B. Shankle, V. Temu, J. Sanborn, and G. Hawkey. 2008. Characterization of deep subsoil strata as suitable plant growth material. The 2008 Joint Annual Meeting of Geology and Agronomy, Houston, Texas [session 776-8].

Leo, R.F., and E.S. Barghoorn. 1976. Silicification of wood. Botanical Museum Leaflets, Harvard University 25, no. 1:1-47.

Lewis, B.A., J.H. Wrenn, A.J. Lewis, J.J. Alford, and D. Alford. 2003. Middle Wisconsinan and recent wet site mummified wood, humus, peat, and pollen, Santa Rosa Island, Florida. Review of Palaeobotany and Palynology 126, no. 3-4:243-266.

Mustoe, G.E. 2003. Microscopy of silicified wood. Microscopy Today 11, no. 6: 34-37.

Mustoe, G.E. 2015. Late Tertiary petrified wood from Nevada, USA: Evidence of multiple silicification pathways. Geosciences 5, no. 4:286309.

Mustoe, G.E. 2017. Wood petrification: A new view of permineralization and replacement. Geosciences 7, no. 4:119.

Oehler, J.H., and J.W. Schopf. 1971. Artificial microfossils: experimental studies of permineralization of blue-green algae in silica. Science 174, no. 4015:1229-1231.

Pettersen, R.C. 1984. The chemical composition of wood. Advances in Chemistry 207, 57-126.

Riggs, N.R., S.R. Ash, A.P. Barth, G.E. Gehrels, and J.L. Wooden. 2003. Isotopic age of the Black Forest Bed, Petrified Forest Member, Chinle Formation, Arizona: An example of dating a continental sandstone. Geological Society of America Bulletin 115, no.11:1315-1323.

Shearer, J.C., T.A. Moore. 1996. Effects of experimental coalification on texture, composition and compaction in Indonesian peat and wood. Organic Geochemistry 24, no. 2:127-140.

Sigleo, A.C. 1979. Geochemistry of silicified wood and associated sediments, Petrified Forest National Park, Arizona. Chemical Geology 26, no. 1-2:151-163.

Taylor, E.L., T.N. Taylor, and M. Krings. 2009. Paleobotany: The Biology and Evolution of Fossil Plants. Boston: Academic Press.

Vassio, E., E. Martinetto, M. Dolezych, and J. Van der Burgh. 2008. Wood anatomy of the Glyptostrobus europaeus "whole-plant" from a Pliocene fossil forest of Italy. Review of Palaeobotany and Palynology 151, no.34:81-89.

Weibel, R. 1996. Petrified wood from an unconsolidated sediment, Voervadsbro, Denmark. Sedimentary Geology 101, no. 1-2:31-41.

Wolfe, A.P., A.Z. Csank, A.V. Reyes, R.C. McKellar, R. Tappert, and K. Muehlenbachs. 2012. Pristine early eocene wood buried deeply in kimberlite from northern Canada. PLoS One 7, no. 9:e45537.

\section{THE AUTHORS}

Dr. Nayeon Lee is a postdoctoral associate at Center for Advanced Vehicular System (CAVS) at Mississippi State University (MSU). She earned her $\mathrm{PhD}$ degree in Biological Engineering and M.S degree in Mechanical engineering at MSU.

Dr. Sungkwang Mun is a postdoctoral associate at Center for Advanced Vehicular System (CAVS) at Mississippi State University (MSU). He earned his $\mathrm{PhD}$ degree in Electrical and Computer Engineering at MSU.

Dr. Mark Horstemeyer is a professor in the Mechanical Engineering Department at Mississippi State University (MSU) where he holds a Chair position for the Center for Advanced Vehicular Systems in Computational Solid Mechanics. He is also the chief technical officer over the manufacturing and design aspects of CAVS. He has published over 350 journal articles, conference papers, books, and technical reports with a citation $\mathrm{H}$-factor of 31 . He has won many awards including the R\&D 100 Award, AFS Best Paper Award, Sandia Award for Excellence, the SAE Teetor Award and was a consultant for the Columbia Accident Investigation Board.

Stephen J. Horstemeyer is a Mechanical Laboratory and Model Shop manager/Mechanical Technologist for the Center for Advanced Vehicular Systems (CAVS) at Mississippi State University for 14 years. Previously, he worked for Sandia National Laboratory in California for a 1-1/2 years and 21 years for Weirton Steel Corporation in West Virginia. In 1994, he graduated for Jefferson Technical College with an AS degree in Design/Drafting Technology. In the year 2005, he established the Materials/ Mechanic Laboratory Facility at CAVS. During his free time, he hunts for fossils, paints signs, and teaches NPS Taekwondo at New Covenant Church. 
Dr. David Lang is a Professor of Agronomy at Mississippi State University who specializes in forage and pasture crops including their establishment of reclaimed lignite mine land drastically disturbed to 100 meters into the sediments of the Mississippi Embayment. These contain eight layers of lignite containing petrified woods that become part of the reclaimed landscape. He has published nearly 200 papers in journal articles or conference proceedings. Dr. Lang has won national awards for his mine reclamation work and has been named as a national Merit Award from the American Forage and Grassland Council and he has been recognized as an outstanding researcher by the American Society of Mining and Reclamation. 